\title{
"The Kesterson Effect"
}

\author{
THERESA S. PRESSER \\ National Research Program \\ US Geological Survey \\ 345 Middlefield Road (MS 435) \\ Menlo Park, California 94025, USA
}

ABSTRACT / Hypothesized to be derived from Cretaceous marine sedimentary rocks, selenium contamination of the Kesterson National Wildlife Refuge is traced through irrigation drainage to the source bedrock of the California Coast Ranges. This biogeochemical pathway of selenium is defined here as the "Kesterson effect." At the refuge ponds, this effect culminated in 1983 in a $64 \%$ rate of deformity and death of embryos and hatchlings of wild aquatic birds. From the previous companion paper on irrigation drainage, the Kesterson effect has been implicated in nine of 11 reconnaissance areas studied in the western United States. Deformities have resulted in at least five of these sites. Climatic, geologic, hydrologic, and soil conditions in these reconnaissance areas are similar to those in the area surrounding Kesterson National Wildlife Refuge in the west-central San Joaquin Valley of California. In California, selenium, as selenate, was ultimately found weathered with sulfur from marine sources in soluble sodium and magnesium sulfate saits, which are concentrated by evaporation on farmland soils. The Se, mobilized by irrigation drainage, is bioaccumulated to toxic levels in refuge wetland ponds that are located mainly in hydrologically closed basins and thus act as concentrating disposal points. The depositional environment of the ponds may be similar to that of the nutrient-rich continental shelf edge and slope in which Cretaceous, Eocene, and Miocene sediments found to be seleniferous in the California Coast Ranges were deposited. Bioaccumulation may be therefore a primary mechanism of selenium enrichment in ancient sediments in addition to that of the formerly suggested Cretaceous volcanic pathway.
The geologic setting and climate of the west-central San Joaquin Valley have created soil salinization problems that have led to the installation of subsurface agricultural drains. Evapotranspiration in the arid climate (19 cm precipitation and $230 \mathrm{~cm}$ evaporation) brings soluble salts to the surface and, with irrigation, shallow saline groundwater near the crop root zone threatens productivity. Grids of tile drains several meters below land surface divert these saline waters to sumps that flow into a collective drain.

Dissolved concentrations of selenium (Se) of up to $1400 \mu \mathrm{g} /$ liter were present in the inflows to the collective San Luis Drain in the west-central San Joaquin Valley (Presser and Barnes 1985). This concentration exceeded the Se criterion for a toxic waste of 1000 $\mu \mathrm{g} /$ liter [US Environmental Protection Agency (USEPA 1980a)]. Speciation studies have shown that Se exists as soluble selenate $\left(\mathrm{SeO}_{4}{ }^{2-}\right)$ in the subsurface waters, thus accounting for its great mobility in water systems.

The terminus of the San Luis Drain was Kesterson National Wildlife Refuge (NWR). After an impact of five years of progressively higher proportions of

KEY WORDS: Selenium; Cretaceous marine sedimentary rocks; Sulfate evaporative salts; Selenoamino acids; San Joaquin Valley: "Rock to duck" drainage water entering the ponds, the concentration of Se reached $350 \mu \mathrm{g} / \mathrm{liter}$, and high rates of embryonic deformity and death in wild aquatic birds, including ducks, coots, stilts, and grebes, occurred at the refuge. In the reducing conditions of the refuge ponds, it was found that Se bioaccumulated in the food chain and its concentration in the diets of birds exceeded that which is known to be injurious (Presser and Ohlendorf 1987). Kesterson NWR was declared a toxic waste dump in 1987 and has since been drained and partly buried. Although the San Luis Drain is presently closed, the farmland irrigation drainage, now routed to the San Joaquin River and on-farm evaporation ponds, represents a class of unregulated pollution (USEPA 1987) in which the $1000 \mu \mathrm{g} / \mathrm{liter} \mathrm{Se}$ designation for a toxic waste (USEPA 1980a) is not enforced (Presser and Barnes 1985) and the $<2.3 \mu \mathrm{g} /$ liter Se suggested limit for the protection of aquatic life (Skorupa and Ohlendorf 1991) is not adopted (Claus 1985).

California, with more than $53,100 \mathrm{~km}(33,000 \mathrm{mi})$ of subsurface drains (Hanson 1989), distributes 570 million cubic meters ( 150 billion gallons) of subsurface irrigation-drainage water annually in the San Joaquin, Coachella, and Imperial Valleys (Ohlendorf and Skorupa 1989). These collection areas include the farmlands that were drained to Kesterson NWR and are drained to the Tulare Lake Bed Area and the 
Salton Sea Area, the other two internal drainage basins located further south in central California. The former active site is in the southern San Joaquin Valley and the latter near the California-Mexico border. The Tulare Lake Bed Area and the Salton Sea Area were two of the reconnaissance sites investigated in the USDOI study discussed in the previous companion paper and found to be contaminated. For perspective, drainage to Kesterson NWR was from only 3240 ha (8000 acres), supposedly a collective representation of 9700 ha $(24,000$ acres $)$, of a potential 242,800 ha $(600,000$ acres $)$ that may need drainage in the west-central part of the valley. A 6474-ha $(16,000$ acre) evaporation pond complex was proposed in 1991 as a disposal alternative for the west-central San Joaquin Valley by the US Bureau of Reclamation (USBR 1991a). In this study of the environmental impacts of these ponds, it was estimated that the Se concentration range in aquatic waterfowl eggs would be elevated to a degree that would cause reproductive failure (50-100 $\mu \mathrm{g} / \mathrm{g}$ Se dry weight).

The contamination of the ecosystem has developed from naturally occurring Se that is thought to have its source in marine sedimentary rocks of Cretaceous age, which historically have been shown to be seleniferous. Alluvial fans derived predominantly from marine formations, which include those of Cretaceous age, of the California Coast Ranges cxist adjacent to the western San Joaquin Valley. These formations are the source of the extensively salinized soils and basinal drainage to farming areas affecting Kesterson NWR. The connection of Se contamination with the extensive sulfate salinity derived from the soils was evident in evaporative sulfate salts containing Se collected on the concrete walls of the San Luis Drain and the significant correlation of Se and sulfate in the inflow waters to the drain.

In this paper, I identify geologic sources of Se in the California Coast Ranges. I also describe mechanisms for mobilization of Se and its transport to and bioaccumulation in the west-central San Joaquin Valley. I present this in a summary model called the "Kesterson effect," which is the biogeochemical pathway of Se extending from "rock to duck." This effect has the essential features of the processes probably occurring in most other sites found to be contaminated in the USDOI reconnaissance study presented in the previous companion paper. Reconnaissance areas were selected with six factors in common with Kesterson NWR and, of the 11 sites found contaminated, nine are in receipt of irrigation drainage derived from Cretaceous marine sedimentary rocks. As will be demonstrated in this study, Se in its most re- duced state (-2), as metallic selenides or as proteinaceous Se, seems to be the state of the starting and ending products of Se enrichment. The former is the seemingly inorganic source of Se, and the latter is the ultimate form bioaccumulated to toxic levels in biota. To provide the connection between geochemical occurrence and bioaccumulation, I add to this picture several discussions. I summarize the primary origin, subsequent history, and extent of enrichment of Se for the geologic formations of the predicted-source Cretaceous marine sedimentary rocks. From the postulated depositional conditions of the seleniferous ancient California Coast Ranges formations and the presentday Kesterson NWR environments, I consider bioaccumulation as a source mechanism and discuss the "abiotic" and "biotic" relationships of Se with sulfur. From the implications of proposed sources other than those developed in the Cretaceous Period, I provide the basis for further reconnaissance and for future remediation and considerations given to placement of reclamation projects. Based on the ecological evidence of the previous paper and the petrological evidence of this paper, it is concluded that the Kesterson effect is prevalent in the western United States.

\section{Selenium Chemistry, Primary Geologic Origin, and Entrance into Cretaceous Formations of California}

The different species or oxidation states of Se are: $\mathrm{SeO}_{4}{ }^{2-}$, selenate $(\mathrm{Se}+6) ; \mathrm{SeO}_{3}{ }^{2-}$, selenite $(\mathrm{Se}+4)$; elemental Se, $(\mathrm{Se} 0)$; and selenides and organic forms of Se (Se-2) [National Academy of Sciences (NAS 1976)]. Selenate, as stated, is soluble and mobile and is found in alkaline, oxidizing environments. As Se is reduced, selenite forms stable iron and aluminum complexes, and upon further reduction, elemental Se is found as an insoluble precipitate. Selenium in its lowest oxidation state can occur as metallic selenides (CuSe, $\mathrm{FeSe}_{2}$, etc.), proteinaceous Se (selenomethionine or selenocysteine), or hydrogen selenide gas $\left(\mathrm{H}_{2} \mathrm{Se}\right)$. All of these species have analogous sulfur species except for selenite.

Selenium is found in rare metallic selenides, although ten different selenides were identificd in one study of epithermal ore deposits, in which Se made up as much as $55 \%$ of the mineral (Davidson 1960). Because of the similar chemical and physical properties of Se and sulfur, data on the primary occurrence of $\mathrm{Se}$ more commonly shows Se concentrated in metallic sulfides. The Se is postulated to be in isomorphous substitution for sulfur due to the similar ionic radii of the sulfide ion $\left(\mathrm{S}^{2-}\right)$ and the selenide ion $\left(\mathrm{Se}^{2-}\right)$ (Cole- 
man and Delevaux 1957). The metallic sulfides associated with magmatic activity contain the most Se, up to $1400 \mu \mathrm{g} / \mathrm{g}$ (Wedepohl 1970). Se is also concentrated in sulfurous volcanic gases (up to $5 \% \mathrm{Se}$ ) and in igneous sulfur deposits (up to $2000 \mu \mathrm{g} / \mathrm{g}$ Se) (Wedepohl 1970). Its presence is noted in encrustation around volcanic vents (Zies 1929), and dust ejected into the atmosphere during volcanic eruptions is also postulated to contain high concentrations of Se (Byers and others 1936).

However, from natural abundances, sedimentary rocks contain more $\mathrm{Se}$ (shales, $0.60 \mathrm{mg} / \mathrm{liter}$ ) than igneous rocks $(0.050 \mathrm{mg} / \mathrm{liter}$ ) (Adriano 1986). It is postulated that, even though magmatic rocks are the primary source of Se, Se, being volatile like sulfur, tends to be depleted in igneous rocks. Under magmatic and hot hydrothermal conditions, Se is made available and is able to move into the sulfide minerals to high concentrations, as noted above. However, in shallow rapidly cooling igneous sources, Se can remain (Davidson 1960). Although few data exist, the same is true of surface ash and ash-flow rocks as opposed to crystalline ones. The ash is more rapidly solidified and thus retains at least part of its Se (Davidson and Powers 1959). The ash rocks, although considered enriched, contain relatively low levels of Se (up to $3 \mu \mathrm{g} / \mathrm{g}$ ) and the crystalline ones contain even less $(<1 \mu \mathrm{g} / \mathrm{g})$.

For the scdimentary rocks in which the majority of Se is held, extensive volcanic eruptions during Cretaceous time are thought to be the primary source through deposition in Cretaceous seas. These seas had invaded the central part of what is now California and a considerable part of the western states (Beath and others 1935, Byers and others 1936). The violent and continued volcanic activity throughout the Cretaceous Period yielded widespread ash falls and flows. Selenium is postulated to have become both incorporated in rainfall from volcanic gases, ash, and dust ejected during eruption and available during the crystallization of magma to be washed into the seas. Continual erosion from volcanic rocks added to the final accumulation of Se in the Cretaceous sedimentary deposits.

During the Cretaceous Period in California, a trough developed along the west side of the continent between a volcanic arc on the east, whose uplifted remains are the present Sierra Nevada, and a marine trench and subduction complex on the west (Presser and Ohlendorf 1987). The central California (or Great Valley) part of this trough, eventually to become the San Joaquin and Sacramento valleys, is estimated to have been $800 \mathrm{~km}(500 \mathrm{mi})$ long and $160 \mathrm{~km}$ $(100 \mathrm{mi})$ wide. It reached its greatest width in the Late
Cretaceous when the sea lapped eastward onto the volcanic arc and erosional products of the arc were deposited in this marine basin.

Also during the Cretaceous Period, approximately along the west side of the current Rocky Mountains, a series of mountainous uplifts formed and were bordered to the east by an asymmetrical subsiding basin (Rocky Mountain Association of Geologists 1972). Throughout most of the Cretaceous this basin was part of a province of epicontinental seas, the Cretaceous Western Interior Seaway, that reached from the Gulf of Mexico to the Arctic Ocean, and is, within the US continental borders, the area of most of the USDOI reconnaissance studies. In the United States the province covered an area up to 1000 miles in width, bounded roughly by the present position of the Mississippi River on the east and the eastern borders of Nevada and Idaho on the west.

Se deposition took place in both these seas during the Cretaceous Period, and eventually, geologic forces of uplift caused the seas to retreat and the sediments to be exposed. These are the Cretaceous marine formations of the California Coast Ranges at the western edge of the San Joaquin and the Sacramento valleys and the outcrops of Cretaceous marine rocks of the Rocky Mountain and Great Plains region. As stated in the previous paper, this latter region comprises a total area of approximatcly $300,000 \mathrm{sq} \mathrm{mi}$ (Trelease and Beath 1949). Because of the widespread exposures of these rocks at the weathering surface, these sedimentary rocks have a great opportunity to interact with water and are the parent materials for many of the soils of the western states. Hence, great opportunities exist for the weathering of Se into the environments present in the western states that are similar to those at Kesterson NWR. Historically, analytical data from the most extensive Cretaceous marine formations of the west, the Pierre and Niobrara Shales, have shown the highest concentrations of Se (maximum $103 \mu \mathrm{g} / \mathrm{g}$; median $6.5 \mu \mathrm{g} / \mathrm{g}$ ) in sedimentary rocks in the western United States (Anderson and others 1961). Further, plants grown on soils derived from these shales were found to be toxic to range animals. Selenium data for California sedimentary formations are scarce, with only one sample of shale from the Upper CretaceousPaleocene Moreno Formation being noteworthy at 28 $\mu \mathrm{g} / \mathrm{g}$ Se (Lakin and Byers 1941).

\section{Sedimentary Geochemical Occurrences of Selenium}

In the drainage areas to Kesterson NWR and in the USDOI study areas postulated to be impacted by sec- 
ondary Se source deposits of Cretaceous marine sedimentary rocks, Se again has been looked for in combination with sulfur. Berner (1984) considers the metallic sulfide, pyrite $\left(\mathrm{FeS}_{2}\right)$, to be the main source of sulfur in marine shales, forming from the reduction of sulfate-containing pore waters during diagenesis. The weathering chemistry of reduced shale (oxidation of pyrite) is largely a reversal of the diagenetic chemistry of the shale (reduction of sulfate). Se is known to substitute for sulfur in pyrite in sedimentary rocks at concentrations up to $140 \mu \mathrm{g} / \mathrm{g}$ in the Cretaceous Mancos Shale of Colorado (Coleman and Delevaux 1957). Krauskopf (1955) cites a maximum of 28 ppm for selenium in sedimentary pyrite in his report on enriched concentrations of metals in shales in semiarid slopes and basins and in organic deposits in swamps. Apart from these sources where sulfur is disseminated, sedimentary rocks also include deposits of coals and ores, which contain sulfur, both known to be enriched in Se. Coals containing the highest concentrations of Se $(100 \mu \mathrm{g} / \mathrm{g})$ also contain the most pyrite and ash (Wehedopl 1970). Up to 3\% Se in pyrite as well as deposits of the metallic selenide, ferroselite $\left(\mathrm{FeSe}_{2}\right)$, the Se analog of pyrite, have been found in surveys of uranium ore deposits in the sedimentary formations of the Colorado Platcau (Coleman and Delevaux 1957). A mineralogic study of these sedimentary Se-bearing sulfides, as in the magmatic ones, has shown rare inclusions of selenides within the sulfides. The Se is again postulated to enter the sulfide structure during deposition. This mechanism will be proven of significance in later suppositions of the paper, as Se is found weathered, but retaining its position in oxidized sulfide minerals. As an example, Se also occurs in concentrations of as much as $1000 \mu \mathrm{g} / \mathrm{g}$ in remobilized sulfides associated with oxidized, sedimentary sandstone-type uranium deposits (Davidson 1963).

\section{Extent of Contamination in the San Joaquin Valley and Location of the Coast Ranges Study Area}

The heavily salinized farmland drainage area that provided return flows to the Kesterson NWR evaporation ponds is in the west-central San Joaquin Valley (Figure 1). This area derives its alluvial deposits primarily from the eastern Coast Ranges where marine sedimentary rocks predominate (Lettis 1982). Ephemeral streams and debris flows that rarely reach the valley axis terminate in the interfan area between Panoche and Cantua Creek alluvial fans (Figure 1). Here, in an almost closed basin effect, the most elevated concentrations of Se (maximum $4.5 \mu \mathrm{g} / \mathrm{g}$; me- dian $1.8 \mu \mathrm{g} / \mathrm{g} \mathrm{Se}$ ) and the greatest salinization were developed in soils (Tidball and others 1989). The irrigated farmlands giving rise to the most contaminated shallow groundwater (up to $12,000 \mu$ g/liter Se) sampled from 1984 to 1986, lie just downslope of the interfan area and at the distal end of the Panoche Creek fan (Deverel and Gallanthine 1989). The fact that Se in soils of the Panoche and Cantua Creek alluvial fans and on the valley floor is not deposited and concentrated along the creek drainages, as in the case of mercury or arsenic, suggests that $S e$ is in a soluble form that has been leached out of the alluvial fans on its way through the valley to the San Joaquin River trough. In subsurface drainage waters from the area shown in Figure 1 that contain Se concentrations up to $1400 \mu \mathrm{g} / \mathrm{liter}$, significant correlations occur between selenium and sulfate $(r=0.93)$ and sodium and sulfate $(r=0.99)$. In the San Luis Drain, evaporative sulfate salts lining the concrete walls contained 17 $\mu \mathrm{g} / \mathrm{g} \mathrm{Se}$.

The study area in the Coast Ranges is essentially between Panoche and Cantua Creeks, west to the drainage divide, and east to the alluvial fans (Figure 1). As seen in detail in Figure 2, the area extends in actuality to Little Panoche Creek in the north and Salt Creek in the south. The sources and observations of physical and chemical processes in the Coast Ranges needed to explain these Se distributions and the resultant model are given below.

\section{Methods and Evaluated Materials}

The methods used for the California Coast Ranges source study are given in Presser and Barnes (1985) and Presser and others (1990). All of the analyses for Se utilized hydride generation atomic absorption spectrophotometry. Care must be taken in pretreatment steps for this method in order to ensure all the different forms of Se are available for signal generation (Presser and Barnes 1984).

A survey was made of 117 bedrock samples, 69 stream sediment samples, 80 water samples, and 64 efflorescent minerals (Presser and others 1990).

\section{Geologic Sources of Selenium}

In the study area, Cretaceous and Tertiary marine sedimentary rocks are the most extensively exposed immediately adjacent to the western edge of the San Joaquin Valley (Bartow 1988a,b, Dibblee 1971, 1973, 1975). Samples of the Upper Cretaceous-Paleocene Moreno Formation and the Eocene-Oligocene(?) Kreyenhagen Shale (Figure 2), contain elevated levels of Se with medians of 6.5 and $8.7 \mu \mathrm{g} / \mathrm{g}$, respectively 
Figure 1. Location of Kesterson National Wildlife Refuge, the farmland drained, and the Coast Ranges study area between Panoche and Cantua Creeks.

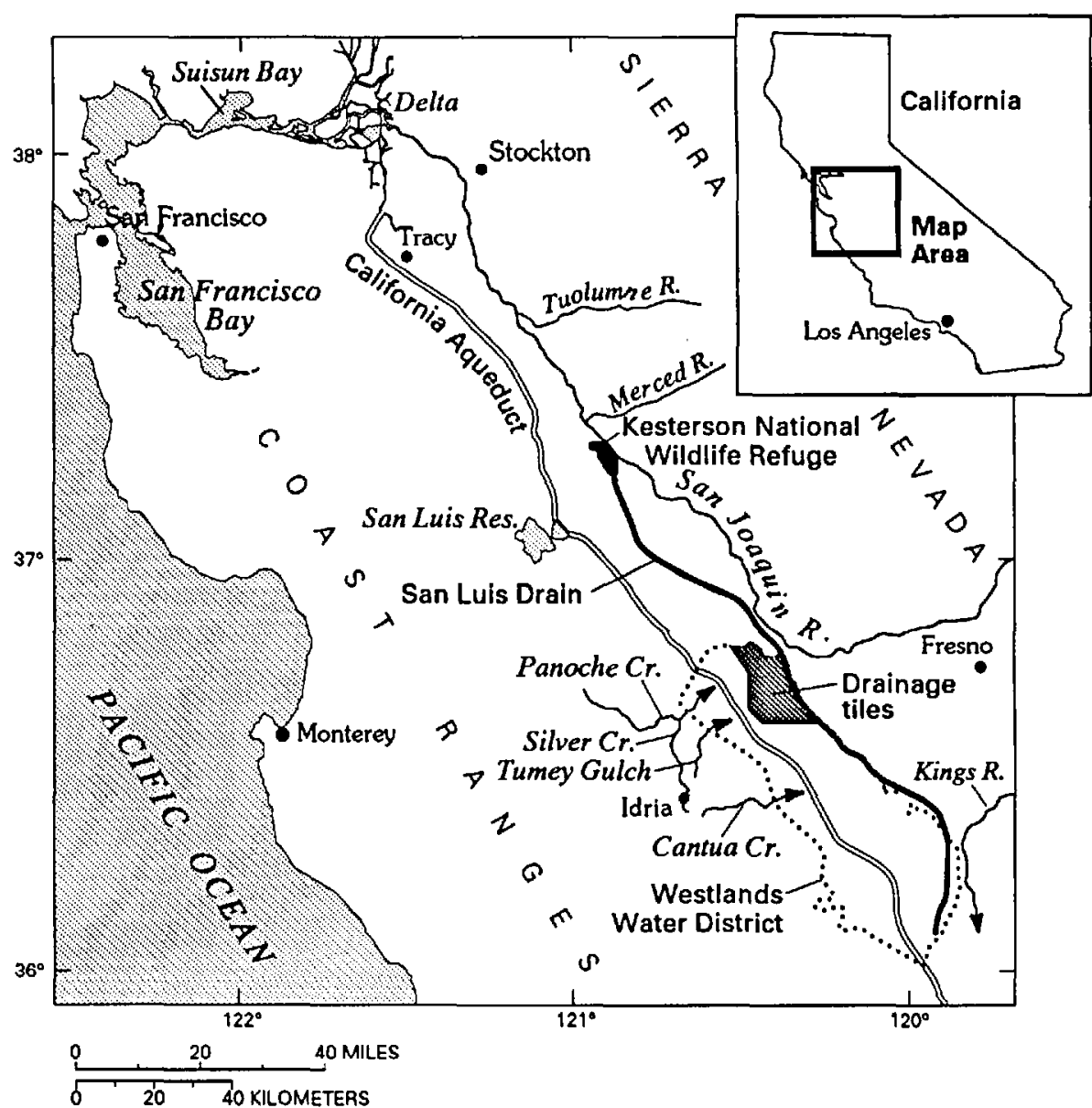

(Presser and others 1990). The Kreyenhagen Shale, as the name implies, and the Moreno Formation, are mainly composed of shale; however, only recently has the Moreno been called "Formation" in the study area, rather than "Shale" (Bartow 1994). Additionally, included in the median value for the Kreyenhagen Shale are Se concentrations from five shale samples of the Eocene Tumey Sandstone Lentil (Bartow 1993) which is now considered a member of that formation. Highest values found were $45 \mu \mathrm{g} / \mathrm{g}$ for the Kreyenhagen Shale and $35 \mu \mathrm{g} / \mathrm{g}$ for the Moreno Formation.

These median values for the Moreno Formation and the Krcyenhagen Shale are in contrast to the overall median of $0.8 \mu \mathrm{g} / \mathrm{g}$ Se found for other formations of extent in the area. These include the Upper Cretaceous Panoche Formation, the PaleoceneEocene Lodo Formation and the Pliocene-Pleistocene Tulare Formation and the unnamed Quaternary nonmarine units. The Upper Cretaceous Panoche Formation mostly consisted of sandstone in the area sampled, therefore allowing the potential for elevated Se values in the shales of that formation in other areas.
Three other geologic features of note in the study area, specifically in the upper reaches of the Panoche Creek drainage, were found barren of Se. No "halo effect" was found from the ore of the New Idria Mercury Mining District, some veins of which contain Se (Boctor and others 1987), nor did the acid mine drainage $(<2 \mu \mathrm{g} / \mathrm{liter})$ or associated stream channel deposits contain Se $(<0.1 \mu \mathrm{g} / \mathrm{g})$. From their characteristic water chemistries, the Franciscan assemblage (bicarbonate) and ultramafic rocks (magnesium ultrabasic) were evaluated and were found not to be probable sources of Se mobilization since only sulfate waters contained Se, as discussed in the next section.

In the USDOI study areas found contaminated by Se in the western United States, nine of 11 areas contain possible source Cretaceous marine sedimentary rocks (Table 2, Presser and others, this volume). For comparison to the Coast Range study area from Lakin's compilation (1961), the most complete to date of Cretaceous marine sedimentary rocks in the western United States, the upper part of the Niobrara Shale and the lower part of the Pierre Shale are shown 


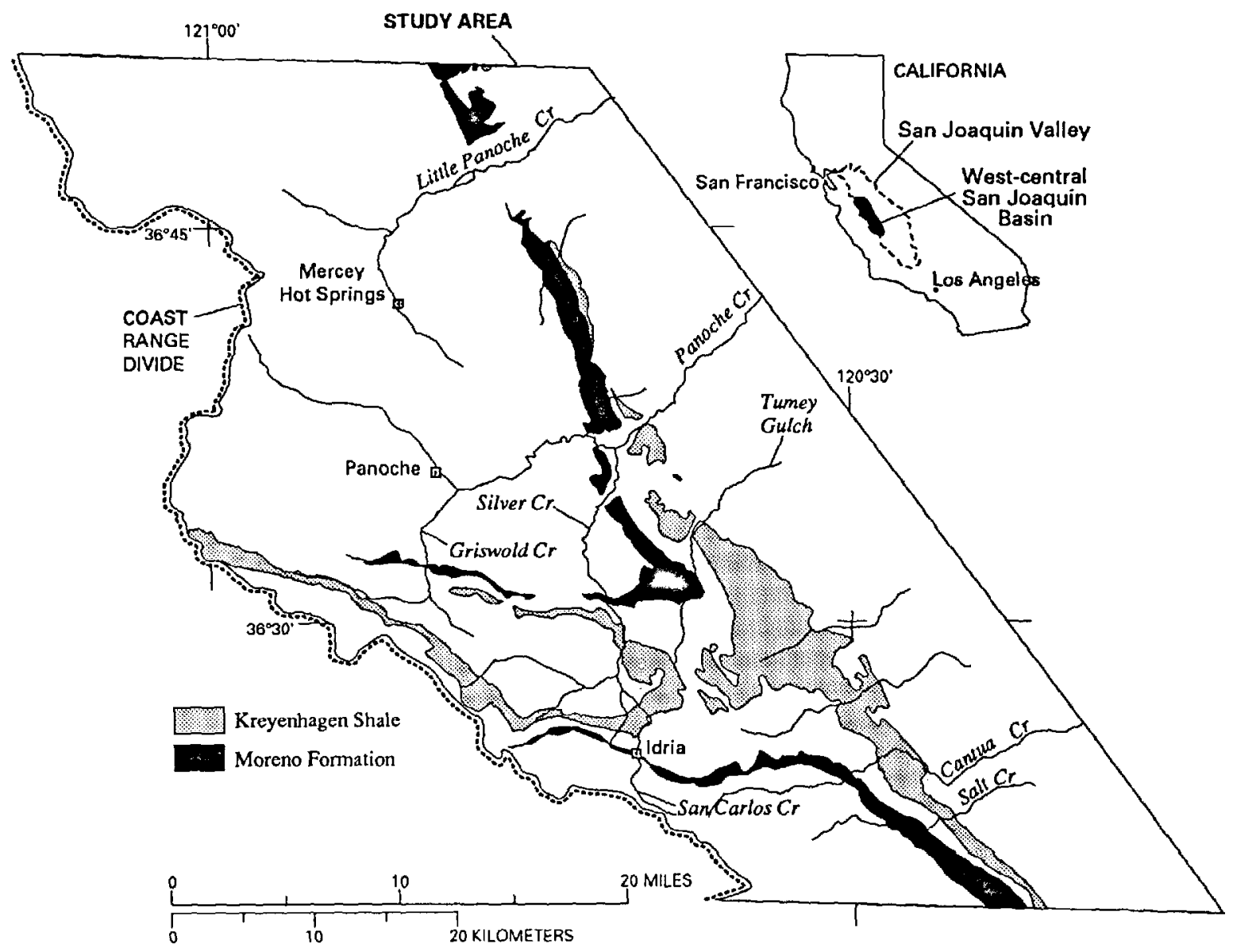

Figure 2. Surficial geology of the seleniferous Kreyenhagen Shale and Moreno Formation in the Coast Ranges study area.

to contain the highest selenium concentrations and to average 20 ppm selenium (range $0.6-103 \mathrm{ppm}$ ). The median values of weighted-average concentrations of selenium in the Pierre and Niobrara shales were 2.2 and $6.5 \mathrm{ppm}$ selenium, respectively. Lakin further concluded that in sedimentary rocks, concentrations of greater than 2 ppm selenium were anomalous.

In California, the proposed depositional environments of the Moreno Formation and the Kreyenhagen Shale are similar, being from continental shelf edge and slope. However, one of these source shales has been subjected to possible enrichment by volcanically evolved Se during the Cretaceous Period. Implications of these settings will be given later in the conclusions for both the California Coast Ranges and the USDOI marine sedimentary basins.

\section{Field Evidence for Selenium Mobilization and Transport}

Highest concentrations of Se in bedrock occurred in summit (median $13.5 \mu \mathrm{g} / \mathrm{g} \mathrm{Se}$ ) and toeslope (me- dian $10.8 \mu \mathrm{g} / \mathrm{Se}$ ) as opposed to midslope (median 5.7 $\mu \mathrm{g} / \mathrm{g}$ Se) positions, suggesting distribution in a soluble phase. Ninety-five percent of the Se in highly weathered samples of the Moreno Formation at higher elevations is soluble selenate.

Material in the seleniferous interfan area is mostly comprised of debris flows and landslide deposits. Highest concentrations of Se in these dynamic parts of the drainage are in a recent mudflow $(4.5 \mu \mathrm{g} / \mathrm{g} \mathrm{Se})$, in debris-flow deposits of ephemeral streams emerging from the foothills (median, $2.8 \mu \mathrm{g} / \mathrm{g}$ Se), and in channel bed sediments (median, $6.8 \mu \mathrm{g} / \mathrm{g} \mathrm{Se}$ ) generated by the Moreno Formation. Erosion is severe from this badland topography (i.e., $85 \%$ devoid of vegetation) and a large sediment load of low-level particulate Se (median $1.2 \mu \mathrm{g} / \mathrm{g} \mathrm{Se}$ ) is delivered to the Panoche Creek alluvial fan. Selenium was highest in these sediments in the fine-grained residual deposit of suspended load of Panoche Creek near its entrance onto the fan $(3.8 \mu \mathrm{g} / \mathrm{g} \mathrm{Se})$.

Saline sulfate waters were found indicative of Cretaceous and Tertiary marine sedimentary rocks of the 
Coast Ranges with the exception of the Panoche Formation, which generates chloride waters. Selenium is associated with the sulfate waters of the two source formations, the Moreno Formation and the Kreyenhagen Shale. The sulfate waters of both acid (up to $420 \mu \mathrm{g} / \mathrm{liter}$ ) and alkaline (up to $3500 \mu \mathrm{g} / \mathrm{liter}$ ) seeps or ephemcral streams contain elevated levels of Se. The acid sulfate seeps, which are widely distributed in the Moreno Formation, are direct evidence of the acid-producing reaction for the weathering of pyrite (Krauskopf 1967) and, by inference, ferroselite $\left(\mathrm{FeSe}_{2}\right)$. The acid sulfate seeps are neutralized, however, by the carbonate component of the sediments, especially that of the adjacent Lodo Formation. As predicted by the $\mathrm{Eh}-\mathrm{pH}$ diagram for Se, this progressive alkalinization aids in the oxidation of Se, thus ensuring the formation and release of soluble selenate as the predominant form of Se. The most concentrated fluid drains to the interfan zone, is strongly buffered by bicarbonate $\left(1415 \mathrm{mg} /\right.$ liter $\mathrm{HCO}_{3}$ at $\mathrm{pH}$ 8.6) while remaining $2 \mathrm{M}$ in sodium sulfate salt, and qualifies as a toxic waste $(3500 \mu \mathrm{g} / \mathrm{g} \mathrm{Se})$.

Extensive effloresences on rock exposures and evaporites along stream beds are hydrous sodiummagnesium sulfate minerals, which also contain elevated concentrations of Se (up to $25 \mathrm{ppm}$ ) in the selenate form. These minerals have open lattice structures due to the presence of up to ten waters of hydration and can tolerate the presence of selenate in the mineral structure. Ten different salts were identified, with mirabilite $\mathrm{Na}_{2} \mathrm{SO}_{4} \cdot 10 \mathrm{H}_{2} \mathrm{O}$ and bloedite $\mathrm{MgNa}_{2}\left(\mathrm{SO}_{4}\right)_{2} \cdot 4 \mathrm{H}_{2} \mathrm{O}$ being the most prevalent.

Transport of soluble Se in the regional aquifer is provided by runoff $(57 \mu \mathrm{g} / \mathrm{g} \mathrm{Se})$, throughflow (18 $\mu \mathrm{g} / \mathrm{g} \mathrm{Se}$ ), perennial groundwater associated with structural synclines $(153 \mu \mathrm{g} / \mathrm{g} \mathrm{Se})$, and deeper (400 ft) well waters ( $58 \mu \mathrm{g} / \mathrm{g} \mathrm{Se}$ ), as opposed to shallower ones $(100 \mathrm{ft})$. Elevated values in runoff and throughflow may imply movement of accumulated salts by episodes of stripping of soluble salts from surface exposures or by rainfall induced groundwater flow.

Isotopic data for water gives additional evidence for the involvement of salts. A plot of $\delta{ }^{18} \mathrm{O} /{ }^{16} \mathrm{O}$ versus $\delta \mathrm{D} / \mathrm{H}$ shows extensive evaporative concentration and suggests one source for all the different types of waters in the area (sulfate, chloride, and bicarbonate) in which dissolution of salts may therefore control water chemistry. Solution-mineral equilibrium data further suggest a solid solution may exist between selenate and sulfate phases and may determine the Se content in water.

These observations are consistent with the documented extensive examples of Se substitution in sulfides presented earlier and suggest similar weathering profiles in which Se and sulfur remain together as they are oxidized. Selenium distribution is characteristic of a system in which $\mathrm{Se}$ is not concentrated in stream sediments but is lost as Se is weathered into the soluble fraction and is washed out. Hence, the Se concentrations in runoff and associated with stream sediment movement (T. S. Presser, unpublished data, US Geological Survey, Menlo Park, California, 1992) are consistent with those measured in soils on the valley floor. That is, the highest concentrations of Se and salinity are found in the depositional environment provided by the ephemeral streams of the interfan area. A low-level residual fraction of Se, although contained in a large quantity of eroded sediment, is delivered to the Panoche Creek alluvial fan.

\section{Supporting Geochemical Evidence from USDOI Study Areas}

While not all-inclusive, a compilation of geochemical observations reported from individual USDOI study areas and isolated historical accounts suggests that seven common factors, which show elevated Se concentrations, are occurring in other sedimentary basins as well as in the west-central San Joaquin Valley: (1) Cretaceous marine sedimentary rocks: implicated as source rocks in nine of the 11 contaminated USDOI study areas (Table 2, previous paper) and historically found to be seleniferous, e.g., Pierre, Mancos, and Niobrara shales (Anderson and others 1961). (2) Pyrite: (a) five samples isolated from the Mancos Shale in the Middle Green RB and found to contain an average of $140 \mu \mathrm{g} / \mathrm{g}$ Se (Coleman and Delevaux 1957), and (b) locally from preliminary cuttings from a well in the San Joaquin Valley and found to contain a high of $11 \mu \mathrm{g} / \mathrm{g}$ Se with background sedimentary rocks averaging $1.7 \mu \mathrm{g} / \mathrm{g}$. (3) Natural acid saline seeps: located in the Sun RB and found to contain 500 and $580 \mu \mathrm{g} / \mathrm{liter} \mathrm{Se}$ with values for $\mathrm{pH}$ of 5.0 and 4.5, respectively. (4) Sodium and magnesium sulfate evaporative salts: (a) accumulated in saline seeps and on farmland soil surfaces from Belle Fourche RPA, Sun RB, and Tulare Lake Bed Area and found to contain $4.4-44 \mu \mathrm{g} / \mathrm{g}$ Se; (b) found in association with the Mancos Shalc as part of the study of the salt load delivered to the Colorado River but not analyzed for Se (Whittig and others 1982); and (c) formed on the walls of drainage ditches carrying up to $2680 \mu \mathrm{g} /$ liter Se in the water in Mesa and Montrose counties of Colorado (ncar the Gunnison RB reconnaissance area), and found to contain 16-260 $\mu \mathrm{g} / \mathrm{g}$ Se (Lakin and Davidson 1967). (5) Sulfate waters in agricultural drains: located in but not limited to Middle Green RB, Salton Sea Area, Kendrick RPA, Tulare Lake Bed 
Area, Angostura RPA, and Belle Fourche RPA and found to contain up to $300 \mu \mathrm{g} / \mathrm{g}$ Se and $50,000 \mathrm{mg} /$ liter dissolved solids; these sites include the three sedimentary sites designated for detailed study. (6) Runoff and snowmelt in flushing events of source area shales: (a) located at the sun RB and found to contain 50-250 $\mu$ g/liter Se (J. H. Lambing, unpublished data, 1991, US Geological Survey, Helena, Montana); (b) located at Rasmus Lee Lake at the Kendrick RPA and found to cause an increase in Se concentration, as snow melted, from 35 to $1300 \mu \mathrm{g} / \mathrm{liter}$ in a matter of days (Naftz and others 1993); and (c) located at Sweitzer Lake in the Gunnison and Uncompahgre River Basins and found to measure $170 \mu \mathrm{g} / \mathrm{liter}$ Se in water in the deepest part of the lake thought to have collected at the bottom of the lake during the winter. (7) Wells: (a) in the Cretaceous Mancos Shale located in the federally irrigated Grand and Uncompahgre valleys of western Colorado and found to contain up to $1300 \mu \mathrm{g} /$ liter Se (W. G. Wright, written communication, USGS, Grand Junction, Colorado, 1992); and (b) indicative of saline seeps in the vicinity of the Bowdoin NWR in the Milk RB, which penetrate the Cretaceous Bearpaw Shale, Judith River Formation, and Claggett Formation, or glacial drift from them and contain up to $188 \mu \mathrm{g} / \mathrm{liter}$ Se (Miller and others 1980). Although little work has been done on the differences between sedimentary sites and volcanic sites, sites designated as volcanic were dominated by chloride anions in agricultural drain waters. However, these sites were not devoid of sulfate, measuring up to $5000 \mathrm{mg} /$ liter at Stillwater WMA and, from historical data, reaching a high of $2590 \mathrm{mg} / \mathrm{liter}$ at Malheur NWR in 1962.

\section{Connection of Bioaccumulation and Geochemical Occurrence}

Marine sedimentary deposits have been uplifted in a series of orogenic events extending into the middle Pleistocene subepoch for both the California and USDOI study areas. Samples of these marine exposures are a composite of the conditions of their depositional environments, the biological and geochemical processes that took place during diagenesis, and the consequent weathering now taking place. What is known from presentday observations is that through weathering in the common climatic and hydrologic settings to that of Kesterson NWR, alkaline soils rich in evaporative salts are also produced at the USDOI sites. Although irrigation practices vary among reconnaissance study areas, they are all similar in that leaching of salts to shallow aquifers and subsequent transport of the leachates to streams and/or wetlands occur. It is in these wetlands and streams that bioaccumulation of Se to potentially toxic levels has been observed. Tracing the route from the geochemical occurrence and weathering of Se to its bioaccumulation in the food chain is complex. The biomineralizing properties and biooxidative-reductive recyclability of Se will again be referred to, as in the previous companion paper. Consideration will be given to the enrichment pathways of Se present in ancient seas to sediments and the ultimate participation of Se in biological cycles.

\section{Enrichment of Selenium and its Association with Sulfur in Biogeochemical Systems}

A positive relationship between total sedimentary Se and both pyrite and organic carbon have been found in the North Pacific Ocean (Velinsky and Cutter 1991). The authors conclude that the correlation between Se and organic carbon indicates that $\mathrm{Se}$ is biologically active (i.e., taken up and incorporated by, for example, phytoplankton), whereas the relationship between Se and pyrite may result from the similar chemical and physical properties of sulfur and Se. The concomitant relationship of Se to both sulfur and carbon is also postulated in the depositional environment under which "black shales" are formed.

Characteristics of black shales are summarized in Bates and Jackson (1980) and hypotheses for their formation are given in Vine and Tourtelot (1970). The Bates and Jackson definition is as follows: Black shales are rich in organic matter and sulfides, especially pyrite (iron sulfide), and contain a suite of trace elements in enriched concentrations over that which is normally found in seawater. Fossils such as plankton are preserved in carbonaceous (as graphitic or carbon films) or sulfurous material (as pyrite replacements). These sedimentary deposits are formed by partial anaerobic decay of buried organic matter in areas such as reducing stagnant marine basins characterized by restricted circulation and a slow deposition of clastic material.

In a study by Piper and Isaacs (1993), they conclude that some concentrations of seawater elements can be accounted for by detrital, terrigenous sources (e.g., Mn, Co, etc.) because of the similarities of concentrations in fecal matter and in the World Shale Average. However, by contrast, contents of "bioreactive elements" such as $\mathrm{Cd}$ and $\mathrm{Zn}$, two elements that appear to be involved mainly in biological cycles of the sea (Broecker and Peng 1982) and that are bioaccumulated, are anomalously high in fecal matter. Selenium falls into this latter category and is especially 
enriched in biogenic debris (zooplankton fecal pellets, $6.6 \mu \mathrm{g} / \mathrm{g}$ Se and surface biogenic particulates, $8.0 \mu \mathrm{g} / \mathrm{g}$ Se dry weight) (Fowler and Knauer 1986) and bottom sediments (up to $5 \mu / \mathrm{g}$ ) (Wedepohl 1970) from modern oceanic systems. Se is also considered to be elevated in plankton (up to $4 \mu / \mathrm{g}$ Se dry weight) and algae (up to $6 \mu \mathrm{g} / \mathrm{g}$ Se dry weight) (G. A. Cutter, unpublished data, 1991, Old Dominion University, Norfolk, Virginia).

Concentrations of Se in presentday seawater are low, covering a range reported in the historical literature of from <1 (Hem 1985) to $4 \mu \mathrm{g} /$ liter (Hill 1963). Although data for Se are scarce, an enrichment factor of 500,000 for Se was estimated by Holland (1979), and a reported black shale from Wyoming contained as much as $675 \mu \mathrm{g} / \mathrm{g}$ Se (Davidson and Lakin 1961). Lakin (1973) proposed enrichment of Se for black shales in sedimentary deposits of the western plains.

In the general sense, the sulfur and carbon cycles have always been connected, with the rates of diagenetic burial of organic carbon and pyrite sulfur positively correlated (Berner and Raiswell 1983). In environments where iron is abundant, the extent of pyrite formation is limited mainly by the amount of organic matter that can be metabolized by sulfate-reducing bacteria (Raiswell and Bcrner 1987). The overall equation for coupling of the carbon and sulfur reservoirs, which constitute a major control on the level of $\mathrm{O}_{2}$ in the atmosphere is:

$$
\begin{array}{r}
15 \mathrm{CH}_{2} \mathrm{O}+8 \mathrm{CaSO}_{4}+2 \mathrm{Fe}_{2} \mathrm{O}_{3}+7 \mathrm{MgSiO}_{3} \\
4 \mathrm{FeS}_{2}+8 \mathrm{CaCO}_{3}+7 \mathrm{MgCO}_{3}+7 \mathrm{SiO}_{2}+15 \mathrm{H}_{2} \mathrm{O}
\end{array}
$$

The direct bacterial mineralization of organic matter by selenate reducers using Se as an energy source has already been discussed in relation to the entrance of Se into the food chain in the previous paper. The fate of this Se and other trace elements during further mineralization of organic materials by sulfides is still debated (Trudinger and others 1972). However, evidence from several sedimentary basins (Degens 1965) provides the connection between geochemical occurrence of Se with sulfur and its bioaccumulation in carbonaceous material. From studies of pyrites of both fresh and marine water origin in carbonaceous shale facies, the sulfide minerals were found to contain the same trace elcment assemblage as that in the associated organic fraction (Keith and Degens 1959, Degens 1965). In specific mineralogic studies, microscopic aggregates of pyrite grains in shale, called framboids, have been described frequently from ancient and recent marine sediments. Their distinctive texture is said to be indicative of biogenic environ- ments (Boctor and others 1987). It is thought that this texture is the result of sulfide crystals replacing or filling the cells of bacteria (Park and MacDiarmid 1970), organic globules (which may be single-celled microorganisms), and/or gaseous vacuoles (Rickard 1970). It is still questioned which mechanism is correct since framboids are formed in both inorganic and organic environments (Trudinger and others 1972). In cases of mineralization of organic material by sulfides associated with seleniferous coals (Wiese 1957) and by ore minerals in sedimentary formations (Coleman and Delevaux 1957), the organic debris seems to have completely controlled the deposition, with the sulfides replacing parts of the cell structure and retaining the Se. For the sedimentary deposits, it is generally assumed that the metals are syngenetic and that a relationship exists between metal content and depositional environment including such factors as concentration of micro- and macroorganisms and the evolutionary stage of oceanic development (Vine and Tourtelot 1970). Thus mineralization of organic matter and replacement by sulfides may preserve the elements that have been previously "biologically packaged." "Biological packaging," a term of Fowler and Knauer (1986), refers to trace elements being transported by large particles, mainly biogenic, in the water column to be deposited with sediments on the ocean floor.

At the Kesterson ponds, sulfate and selenate are significantly correlated $(r=0.96)$ and total dissolved solids range from $>10,000$ to $24,000 \mathrm{mg} /$ liter, which classifies these waters as "very saline" (Hem 1970). Conditions developed at these ponds from this concentrated influx of sulfate and selenate to an environment rich in plankton and benthos may parallel those under which black shales were formed through geologic time. The concentrations of Se in the presentday organic bottom material at Kesterson NWR compare or exceed those of the ancient Coast Ranges sedimentary deposits.

As suggested from the associations presented above and by the known correlation of sulfur and Se in the soluble systems of the Coast Ranges and San Joaquin Valley study areas, two hypotheses therefore present themselves for the cnrichment of Se in sulfides in sedimentary rocks. Are relationships primary, i.e., can an "abiotic condition," whereby seleniferous diagenetic pyrite forming from the reduction of sulfate-containing marine pore waters volcanically enriched in Se, account for Se concentrations found in Cretaceous formations of the Coast Ranges? Or are relationships secondary, i.e., "biotic," whereby Se is initially collected in biogenic material when microbes 
are still active in the sediments and then the organic matter further mineralized by sulfur? Sulfur is supplied from the sea above by sulfate reducers and consequently the Se is either diagenetically released and deposited in metallic sulfides or retained in the cell structure of the organic matter during pyritization. This latter proposed pathway for "bioreactive elements," inclusive of those involved in biological cycles in areas rich in nutrients, masks the link to their first being bioaccumulated in carbonaceous food-chain materials. As will be postulated below, both types of enrichment are possible in the Coast Ranges study area since seleniferous remnant sedimentary deposits from the Cretaceous and those formed under nutrient-rich upwellings are present.

\section{Observations and Limitations of California Coast Ranges Reconnaissance}

From their petrologic descriptions, the Upper Cretaceous-Paleocene Moreno Formation and EoceneOligocene(?) Kreyenhagen Shale, found to have the highest Se concentrations in bedrock of the Coast Ranges study area, are proposed to have formed in similar depositional environments. They were accumulated in areas of the continental shelf edge and the adjacent continental slope where marine upwellings of nutrient-rich water often leads to periodic plankton blooms (McGuire 1988, Milam 1985, Schoellhammer and Kinney 1953, and Payne 1951). Foraminiferal assemblages in the interval of the Moreno Formation and Panoche Formation $(1786-4609 \mathrm{~m})$ from the "Shaw 1-16 Well" of the Shell Oil Company, located downslope of the study area on the valley floor, contain bathyal and neritic species indicative of continental shelf and slope environments (W. V. Sliter and M. McGann, unpublished data, 1985, US Geological Survey, Menlo Park, California). Both shales are also described by Anderson and Pack (1915) as especially diatomaceous and foraminiferal. They investigated the potential oil resources of the west border of the San Joaquin Valley north of Coalinga to San Francisco and concluded that the oil-bearing zones of this region are the two organic shale rock units, the Moreno Formation and the Kreyenhagen Shale.

The Coast Ranges Miocene Monterey Formation of similar biogenic nature, although not present in the study area, is a suspected source of Se for the Tulare Lake Bed Area evaporation ponds, which are further south on the west side of the San Joaquin Valley. These ponds are the site of deformed birds (up to a rate of $38 \%$ teratogenicity), and the area was found to be one of the most contaminated in the USDOI reconnaissance studies. Recent studies show Se concentrations comparable to those in the Moreno Formation and Kreyenhagen Shale (Piper and Isaacs 1993).

Examples of seleniferous formations of various geologic ages other than Cretaceous also exist in the literature. The Upper Devonian Gibellini facies of the Woodruff Formation in central Nevada (Desborough and others 1984) is a metalliferous oil shale containing up to $415 \mu \mathrm{g} / \mathrm{g}$ Se in its zones of less intense oxidation. Evidence shows the formation to have been deposited in a continental-rise setting on an inner-arc basin that was periodically anoxic. The area received abundant organic debris from near-surface marine waters that contained a great concentration of phytoplankton.

The limitation of Se sources to Cretaceous seas in California may therefore be questionable. In addition to the volcanic inputs of the Cretaceous Period, biogeochemical cycling of Se may have been at work also over this time period as well as in the Miocene and Eocene epochs, when upwellings off the coast affected the enrichment of the Coast Ranges sedimentary rocks in Se. The postulated nutrient-type, bioreactive function of the element Se under these reaction conditions suggests the importance also of a possible "biotic" (bioaccumulative) mechanism of enrichment from seawater. On a smaller time scale and under more concentrated conditions, this same type mechanism may have taken place at Kesterson NWR in the present, providing a modern analog. The added result at the refuge, however, is known aquatic bird deformities.

The correlation of both Se and salinity in soils and of Se and sulfur in salts and waters, derived from the postulated-source Cretaceous marine shales, represent a co-occurrence; however, a co-genesis has not been proven. The source material studied in California is so extensively weathered that no organic matter remains. Hence, not all the primary associations of Se were able to be investigated (i.e., Se versus organic matter, phosphates, silicates and the metals of selenides) in this source reconnaissance study. However, what is explicit is that the extensive mobilization of Se from a disseminated source has provided a connection between the geologic and ecologic cycles of the San Joaquin Valley. Kesterson NWR was originally designed to regulate flows from the San Luis Drain to its final terminus at the San Francisco Bay Delta Estuary. If drainage waters had not been collected and concentrated at the refuge ponds, birds would not have been exposed to the teratogenic and lethal levels of the toxicant Se and the Kesterson ef- 
fect, which is summarized below, discovered, before irreparable ecological harm had been done to the delta.

\section{"The Kesterson Effect"}

Called the "Kesterson effect" (Figure 3), processes proposed for the biogeochemical cycling of Se in the west-central San Joaquin Valley of California are as follows: (1) Selenium was enriched in ancient seas during the Cretaceous Period and the Eocene and Miocene epochs, which leads to Se incorporation in marine sediments either from (a) the washing in and deposition of volcanic eruptive material, or (b) the biogenic accumulation from seawater into the food chain at sites of nutrient-rich continental slope upwellings. (2) Selenium was substituted for sulfur, either "abiotically" or "biotically," in sulfides formed during diagenesis of sediments, which results ultimately in high concentrations of Se in pyritic marine shales. (3) The seas retreated and the Coast Ranges shales were uplifted during the Tertiary Period, which leads to exposure of seleniferous sedimentary rocks. (4) Source shales are rapidly weathered in an arid climate, which produces unstable, steeply dipping slopes mostly devoid of vegetation. (5) Mass wasting in the form of mud and debris flows is accelerated and high volumes of sediments are delivered in fastflowing streams of short duration, which develop extensive alluvial fan areas. (6) Particulate reduced and intermediate oxidation states of Se are transported to the valley, which results in the constant renewing of a low-level background concentration of Se in soils. (7) Upon further weathering of the shales in the Coast Ranges, acid is produced and Se released during the oxidation of pyrite, which generates briny, seleniferous, sulfate seeps of $\mathrm{pH} 4$ found indicative of source shales. (8) With continuing neutralization by introduction into an alkaline carbonate environment and the evaporative concentration of these waters, fractional crystallization of sulfate minerals yields soluble selenate incorporated in hydrous sodium and magnesium sulfate salts. (9) These salts are effectively concentrated by water movement from the capillary fringe through many evaporation-dissolution cycles on summit slopes, creating salt crusts, and from downgradient subsurface flow on toeslopes, creating salt-layering. (10) The salts are extensively mobilized in both solid and aqueous phases, which provides a main mechanism of transport of Se, i.e., (a) mass wasting of salts generates high concentrations of $\mathrm{Se}$ in recent debris and mud flows; and (b) solubilization of salts in the regional watershed generates high concentrations in runoff and throughflow from the flushing events of winter. (11) Oxidation of particulate Se transported from above is promoted by alkaline soil surfaces on the valley floor, which produces additional selenate salts on farmland soils. Irrigation leaches the salts, including $\mathrm{Se}$, into the existing shallow groundwater aquifer that is drained to surface canals by subsurface tile systems.

Until 1986, the San Luis Drain collected subsurface drainage containing high levels of Se and transported it to Kesterson NWR. Alternatively, if this groundwater is pumped to lower the water table, not only is the upper aquifer further degraded, but conduits for the drawdown of Se contamination may be provided by thousands of wells that, in many cases, connect the extensive upper and lower San Joaquin Valley aquifers. The latter aquifer provides good quality water and is utilized as a drinking water supply. In 1951 Davis and Poland (1957) counted $>1000$ wells for large-scale groundwater irrigation prior to importation of surface irrigation supplies. An estimate in 1990 by Quinn and others (1990) located 533 wells perforating both aquifers. A total of 1200 wells were drilled in 1991 alone, to compensate for the drought in California of the last five years. At least some of these latter wells are of a new dcsign whereby waters from both aquifers are mixed to lower total dissolved solids present in the upper aquifer before the water is issued. Minimum life (i.e., total dissolved solids $>2500 \mathrm{mg} /$ /iter) of the upper aquifer is estimated at 25 years in some agricultural parts of the San Joaquin Valley, if this proposed, redefined disposal practice of subsurface drainage is practiced [San Joaquin Valley Drainage Program (SJVDP 1990)]. No estimate of the effect on the deep aquifer was made since its preservation, not its involvement, was considered at the time. Through pumping since the drought began, in mainly 1991, the lower aquifer is at preaqueduct levels and pumping is being allowed at the same rate in 1992 even though signs of subsidence are already in evidence.

When the seleniferous subsurface drainage is transported into a highly productive, organic-rich reducing basin like Kesterson NWR, Se is either incorporated inorganically into sediment or bioaccumulated organically directly into the food chain. These processes, reflecting the complexities of its oxidationreduction chemistry, are summarized as follows from Presser and Ohlendorf (1987) and Lemly and Smith (1987). Incorporation in sediment could take place through a strictly chemical reduction of Se, which 


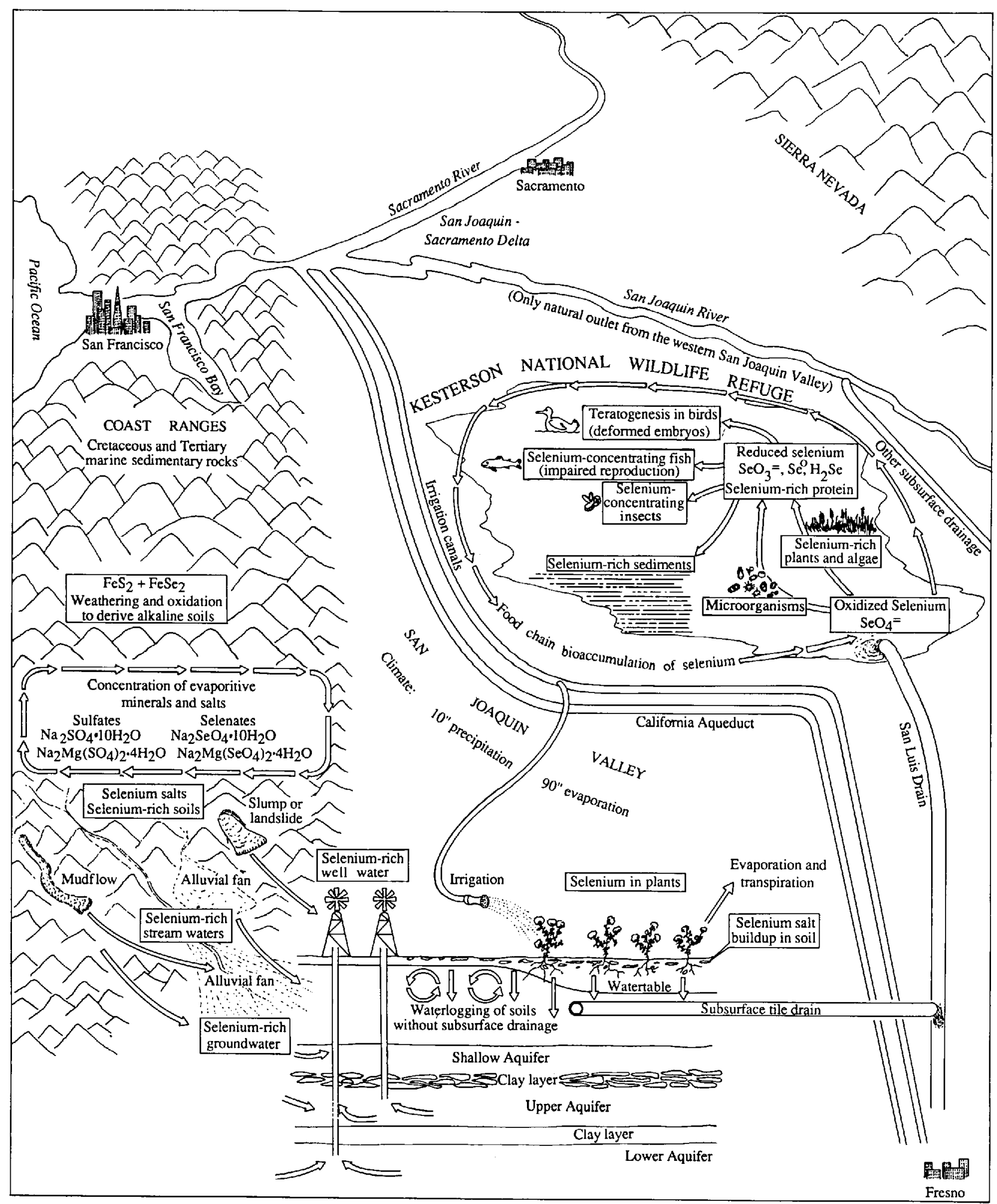

Figure 3. The Kesterson effect: biogeochemical cycling of selenium in the Coast Ranges, the San Joaquin Valley, and Kesterson National Wildlife Refuge of California. 
would result in adsorption of selenite on ferric oxide surfaces and precipitation of insoluble elemental Se. Organic-rich bottom material, however, contains the most Se (up to $130 \mu \mathrm{g} / \mathrm{g}$ ). Bioaccumulation in the food chain can occur through reduction by microorganisms, algae, or plants. Ensuing cellular processes include replacement of sulfur by Se in sulfur-containing amino acids and, hence, proteins, methylation and possible volatilization of Se to selenide gas, and deposition of elemental Se on cell membranes and walls. At Kesterson NWR, increasing amounts of Se were found in benthos, plankton, algae, rooted plants, insects, and fish (up to $247 \mu \mathrm{g} / \mathrm{g}$ Se in mosquitofish) as bioaccumulation took place. Biomagnification of $\mathrm{Se}$ in the organs of higher food-chain organisms occurs through consumption of the consequent Se-rich diet once the primary producers introduce it into the food chain. Selenium toxicity studies of cells of higher organisms, mammalian in addition to avian, show impaired reproduction and developmental abnormalities, inhibition of growth, mutagenesis (including a positive Ames Salmonella assay), and suppression of the immune system. Selenium incorporated into sediments (loading) can be mobilized into the food chain at any time as conditions for biological growth become high, for example, as water becomes slow moving. On a larger scale, oxidative reactions at any stage in these processes lead to recycling of Se. These processes mainly involve mixing of waters by burrowing and feeding organisms, photosynthesis by plants and, of course, cycling by microorganisms. Consequently, when this sediment is again weathered, sulfates are formed and the cycle starts over again. Evidence from biological systems presented earlier suggests these oxidation-reduction processes could be taking place simultaneously in pond environments.

\section{Contaminated USDOI Reconnaissance Sites and Their Possible Geologic Sources}

The extensive areal development in the western United States of the Cretaceous Western Interior Seaway and its downwind relationship to volcanic fields in the Rocky Mountain region provided a greater opportunity for volcanic Se deposition in marine sediments than in California. This would emphasize the importance of an "abiotic" mechanism, based on the similar physical and chemical properties of Se and sulfur, as a possible main source of Se in most of the areas covered in the USDOI reconnaissance studies. The shorelines of the Cretaceous seaway were, however, characterized by a chain of barrier bars that separated extensive lagoons and estuaries from the open sea (Rocky Mountain Association of Geologists 1972). When conditions were favorable, large areas near the coasts were covered by swamps inhabited by dinosaurs and eventually became the sites of coal deposits. Therefore inland sea depositional conditions rich in nutrients did exist in this Rocky Mountain region, thus still evoking possible, additional, "biotic" enrichment.

\section{Primary Volcanic and Secondary Sources}

A further question raised by this study is the possible contribution of Se from the volcanic environments present at two of the reconnaissance areas, Malheur NWR and Stillwater WMA, which have ecological damage. Selenium analyses have traditionally not been included in geologic assessments, probably due to analytical difficulties, and therefore little Se data can be quantified for the Se contamination addressed here. Tuffs of pyroclastic origin exist in the general vicinity of these areas and evidence from another area leads back to the direct involvement of volcanic primary sources. The so-called Wyoming "Lysite tuff" of Davidson and Powers (1959), a water-laid ash, called an atypical volcanic deposit, contains up to $500 \mu \mathrm{g} / \mathrm{g}$ $\mathrm{Se}$ in a soluble form. As indicated from the depositional pattern, the original Se concentration in the tuff is thought to have been remobilized in the groundwater (Coleman and Delevaux 1957).

Some observations reported in the literature of elevated Se concentrations in secondary sources include: (1) movement of Se in hydrothermal fluids derived from igneous intrusive rocks (Coleman and Delevaux 1957); (2) the location of most of the seleniferous epithermal ore deposits of the United States (mainly of Tertiary age) in the same area as that of the sedimentary rocks giving rise to the seleniferous soils of the western United States (Davidson 1960); (3) uranium-vanadium roll-front deposits resulting from the expulsion of oxidized seleniferous ore-bearing solutions from load-compacted volcanic tuffs into permeable sandstones and transportion by connate waters into reducing environments (Park and MacDiarmid 1964); and (4) the possible separation of sulfur and Se at some conversion temperature (Wedepohl 1970) during the devitrification process (Park and MacDiarmid 1964) of rapidly cooling magmatic glasses. Coleman and Delevaux (1957) conclude, in a general sense, that the ultimate source of Se in sulfides from the Colorado Plateau and Wyoming can be related to a magmatic province that has contained 
exceptionally high Se during periods of volcanic and intrusive activity in Mesozoic and Tertiary time.

\section{Human Considerations and Remediation}

The possible pathways of contamination of the terrestrial food chain are now of concern in the San Joaquin Valley of California. Selenium has the smallest margin of any essential element between what is safe $(50-200 \mu \mathrm{g} /$ day/adult $)$ and what is toxic $(500 \mu \mathrm{g} /$ day/adult) (USEPA 1980b). Safe and adequate ranges of daily Se intake vary by about an order of magnitude between infants and adults ( $10 \mu \mathrm{g} /$ day vs $200 \mu \mathrm{g} /$ day $)$. The question of the chemical form of Se ingested has not been cxtensively addressed but is known to affect toxicity (NAS 1976). As more research is done on levels of Se necessary for the protection of aquatic life, thresholds become lower and lower, yet in July 1992 the drinking water criterion for Se will be raised from $10 \mu \mathrm{g} /$ /iter (Presser and Ohlendorf 1987, USEPA $1980 \mathrm{~b}$ ) to $50 \mu \mathrm{g} / \mathrm{liter}$ (USEPA 1991) by the US Environmental Protection Agency. No recent "market basket" data to evaluate the intake from food sources, which are postulated to have increased due to Se supplementation in animals and reclamation of seleniferous lands on which grains are grown, nor long-term data in man, which are known to be a necessary adjunct to lower animal studies, were presented for the basis of this decision. The increase was based on only one case study of endemic Se intoxication in China (Yang and others 1983). Commentators on the USEPA's decision based on Yang's work recommended both lower and higher criteria, thus showing the inconclusiveness of this one study. The essential component of this evaluation seemed not a benefit, but rather a lowering of the standard of risk associated with a substance that has proven to be hazardous to the environment.

The future production and management of Secontaminated agricultural drainage water are also now of concern in the San Joaquin Valley (USBR 1991a). Presented here are some possible in-valley solutions, none of which alone solves the drainage problem. Most of these solutions are stop-gap measures that prolong the farmability of affected lands. Possible cutbacks in production of seleniferous saline brines could be sought through: more efficient irrigation systems (drip versus flood) that create less drainage water; land retirement in the areas of greatest salinization, thus reducing the amount and increasing the concentration of the brine; pumping of shallow groundwater before irrigation deliveries to help prevent build-up of waterlogged soils that need to be drained; and encouragement of water conservation as required by a reallocation of available water through water marketing to meet changing state demands. Monitoring of quantity and quality of the drainage would be an integral part of all of thesc production alternatives. Management or remediation of drainage can be handled in a number of different in-valley ways that include both natural or technology-oriented options: evaporation ponds to concentrate drainage; agroforestry plots to intercept water moving to downslope farms; fewer channels that carry drainage to minimize contact with wildlife; and "timed" drainage at occasions of high flows of natural outlets including the San Joaquin River to further dilute the drainage water. Brine from final stage reuse may be disposed of by cartage to landfill, injection into geologic formations, or used in solar or cogeneration facilities. The ultimate solution proposed for out-ofvalley disposal of the by-product brine is to the ocean, probably through overland piping.

The most promising remediation technique being tried in the San Joaquin Valley is a biogeochemical process that is intrinsic to the nature of the "biotic" theory of enrichment of ancient and presentday sediments. It is based on the use of microbes thought to be ubiquitous that are found in several types of sediment. In a controlled environment, reduction of soluble selenate to insoluble elemental Se would be a natural remediation technique, leaving Se sequestered in sediments. Chemical reduction has proven unfeasible due to the rigorous conditions necessary and their consequent environmental hazards, but microbes complete the task easily in a short time. Several strains of anaerobic bacteria that use selenate as a food source are being used in a bioremediation plant in the San Joaquin Valley that has a $90 \%$ reduction rate during the warmer times of the year. A natural product could be produced by these biological reactor columns that might be used as a Se supplement in feed for animals in Se-deficient areas. This remediation technique is based on the fundamental processes of biogeochemistry and, together with the suggestions for management and cutback in production of drainage water, offers a view for minimizing the environmental hazard presented here. However, water policy issues yet to be addressed are given below.

\section{Concluding Perspectives}

The intricate pathway between Se geologic sources and bioaccumulation in biota has been traced, i.e., from "rock to duck." The problems attendant to the 
dispersal of such a chemically and biologically complex element as Se have resulted in the generation of the Kesterson effect. The bioaccumulative mechanism of Se enrichment seen in the ponds may have also functioned as a primary source in ancient sedimentary deposits based on work done in the California Coast Ranges. Thus, the biogcochemical cycle has come full circle from the weathering of reduced-state selenide minerals to selenate and the consequent production of the reduced-state proteinaceous material, the ultimate form bioaccumulated to toxic levels in biota. This seleniferous organic matter will be deposited, undergo diagenesis, and be capable of mobilizing its Se if these sedimentary deposits are exposed to oxidizing conditions. This proposed scenario did happen at the buried Kesterson NWR site, where winter rains caused oxidizing conditions and selenate salts were wicked to the surface, creating a further hazardous site to wildlife, which included high levels of Se in the terrestrial food chain (USBR 1991b).

Similar potential for the Kesterson effect may also be present in ecosystems with settings that correspond hydrologically, geologically, and biologically to that surrounding Kesterson NWR and that were studied by the USDOI (Presser and others, previous paper). Nine of 11 of the USDOI study areas found to be contaminated by Se are known to have salinized soils derived from Cretaceous marine sedimentary rocks of the Rocky Mountain and Great Plains region. The seleniferous leachates from these soils, generated by the same mechanisms proposed in the Kesterson effect, are delivered through irrigation drainage to refuge areas in which Se is bioaccumulated to levels associated with adverse reproductive effects in wildlife. Two refuge sites are also affected by surrounding volcanic rocks.

Selenium originating from the primary source volcanic rocks and/or the secondary source Cretaceous marine sedimentary rocks shows particular concentration in an area surrounding a cluster of contaminated USDOI areas (sites $11,12,13,14,16$, and 17 of Figure 1, previous paper). These areas are in the regions of the Rocky Mountain Province and the Colorado Plateau but also include most of the state of South Dakota and the southeastern part of the state of Colorado. The refuges in this cluster may be indicative of accompanying Se pollution produced areally in these geologic provinces, which is then collected and drained by some of the major river systems of the western states. This effect could have far-reaching consequences downstream, both aquatically and with respect to Se loading of sediments. In the Missouri River system, the Kendrick RPA (North Platte River),
Belle Fourche RPA (Belle Fourche River), and Sun $\mathrm{RB}$ (Sun River) may provide such evidence as would the Gunnison RB/Grand Valley Project (Gunnison and Uncompahgre rivers) and Middle Green RB (Green River) on the Colorado River system. This has already been suggested in the previous paper by the report of elevated Se data from the lower Colorado River Valley and the Salton Sea Area near the terminus of the Colorado River system. Lastly, the middle Arkansas River Basin would be evidential for the Arkansas River system.

Many issues have been raised by the presence of Se in agricultural subsurface drainage, and will continue to be raised, if the proponents of western water projects do not consider irrigation-induced waterquality problems. A few of these issues are the federal exemption of agricultural drainage as a class of known pollution, the continued use of agricultural drainage in NWRs where it is a known cause of teratogenicity, the definition of pollution based only on water-quality standards of an element that is known to bioaccumulate to toxic levels in higher-food-chain organisms, the use of unregulated evaporation ponds attractive to wildlife as a means of disposal for a known toxin that eventually causes the generation of hazardous waste dump sites, the possible loading of sediments with Se and detriment to the food chain when concentrates of Se are dumped in river systems in an attempt to dilute the pollutant, the lack of groundwater management programs, in which, for example, California does not restrict pumping, and the use of land whose salinity and/or selenium content would classify it for retirement.

The scientific findings given in these two papers, in conjunction with the continuing reconnaissance and detailed studies, may enable government agencies to better manage natural resources that they hold in public trust for the people. Ecological renewability is considered a key issue in the management of natural resources, and it may be in jeopardy in the areas described.

\section{Acknowledgments}

Members of the US Gcological Survey who deserve thanks are: W. C. Swain, R. R. Tidball, and R. C. Severson for assistance with selection and collection of water and geologic samples; and Alan Bartow and David Piper for their thoughts on the evolution of the Moreno and Monterey Formations and the Kreyenhagen Shale. Coast Ranges study work was prepared in cooperation with the San Joaquin Valley Drainage Program. 


\section{Literature Cited}

Adriano, D. C. 1986. Trace elements in the terrestrial environment. Springer-Verlag, New York, 533 pp.

Anderson, R., and R. W. Pack. 1915. Geology and oil resources of the west border of the San Joaquin Valley north of Coalinga, California. US Geological Survey Bulletin 603:220 pp.

Anderson M.S., H. W. Lakin, K. C. Beeson, F. F. Smith, and E. Thacker. 1961. Selenium in agriculture. US Department of Agriculture Handbook 200, 65 pp.

Bartow, J. A. 1988a. Preliminary geologic map of the Lillis Ranch quadrangle, California. US Geological Survey Open-File Report 88-49, 1 sheet, scale 1:24,000.

Bartow, J. A. 1988b. Preliminary geologic map of the Monocline Ridge quadrangle, California. US Geological Survey Open-File Report 88-528, 1 sheet, scale, 1:24,000.

Bartow, J. A. 1994. Geologic map of the west border of the San Joaquin Valley in the Panoche Creek-Cantua Creek area, California. US Geological Survey Miscellaneous Investigations Map no. IZ430 (in press).

Bates, R. L., and J. A. Jackson (eds.). 1980. Glossary of geology. American Geological Institute, Falls Church, Virginia, $751 \mathrm{pp}$.

Beath, O. A., H. F. Eppson, and C. S. Gilbert. 1935. Selenium and other toxic minerals in soils and vegetation. Wyoming Agriculture Experimental Station Bulletin 206:1-54.

Berner, R. A. 1984. Sedimentary pyrite formation: An update. Geochimica et Cosmochimica Acta 48:605-615.

Berner, R. A., and R. Raiswell. 1983. Burial of organic carbon and pyrite sulfur in sediments over Phanerozoic time: A new theory. Geochimica et Cosmochimica Acta 47:855-862.

Boctor, N. Z., Y. N. Shieh, and G. Kullerud. 1987. Mercury ores from the New Idria Mining District, California: Geochemical and stable isotope studies. Economic Geology 51:1705-1715.

Broecker, W. S., and Tsung-Hung Peng. 1982. Tracers in the sea. Lamont-Doherty Geological Observatory, Columbia University, Palisades, New York, 690 pp.

Byers, H. G., K.T. Williams, and H. W. Lakin. 1936. Selenium in Hawaii and its probable source in the United States. Indusirial and Engineering Chemistry 8:821-823.

Claus, R. J., v. California State Water Resources Control Board. 1985. Resulting in Amendments to the Water Quality Control Plan for the San Joaquin Basin WQ 85-1 for the Control of Agricultural Subsurface Drainage Discharges, California Central Valley Regional Water Quality Control Board, Sacramento, California, 1988,61 pp.

Coleman, R. G., and M. Delevaux. 1957. Occurrence of selenium in sulfides from some sedimentary rocks of the western United States. Economic Geology 52:499-527.

Davidson, D. F. 1960. Selenium in some epithermal deposits of antimony, mercury and silver and gold. US Geological Survey Bulletin 1112A:1-17.

Davidson, D. F. 1963. Selenium in some oxidized sandstonetype uranium deposits: US Geological Survey Bulletin 1162. C:C1-C33.

Davidson, D. F., and H. W. Lakin. 1961. Metal content of some black shales of the western United States. US Geological Suriey Professional Paper 424:329-331.
Davidson, D. F., and H. A. Powers. 1959. Selenium content of some volcanic rocks from western United States and Hawaiian Islands. US Geological Survey Bulletin 1084-C:81 pp.

Davis, G. H., and J. F. Poland. 1957. Ground water conditions in the Mcndota-Huron area, Fresno and Kings counties, California. US Geological Survey Water-Supply Pa. per 1360-G:409-588.

Degens, E. T, 1965. Geochcmistry of sediments: A brief survey. Prentice-Hall, Englewood Cliffs, New Jersey, 342 pp.

Desborough, G. A., F. G. Poole, R. K. Hose, and G. N. Green. 1984. Metalliferous oil shale in the upper Devonian Gibellini facies of the Woodruff Formation, southern Fish Creek Range, Nevada. US Geological Survey Bulletin 1694:93-104.

Deverel, S. J., and S. K. Gallanthine. 1989. Relation of salinity and selenium in shallow groundwater to hydrologic and geochemical processes, western San Joaquin Valley, California. Journal of Hydrology 109: 125-149.

Dibblee, T. W. 1971 . Geologic maps of seventeen 15-minute quadrangles. US Geological Survey Geologic Map.

Dibblee, T. W. 1973. Stratigraphy of the southern Coast Ranges near the San Andreas Fault from Cholame to Maricopa, California. US Geological Survey Professional Paper 764:45 pp.

Dibblee, T. W. 1975. Geologic map of the Pacheco Pass, Hollister, Quien Sabe, Ortigalita Peak, San Benito, Panoche Valley and Tumey Hills quadrangles, San Benito, Santa Clara, Merced, and Fresno counties, California. US Geological Survey Open-File Report 75-0394.

Fowler, S. W., and G. A. Knauer. 1986. Role of large particles in the transport of elements and organic compounds through the oceanic water column. Progress in Oceanography 16:147-194.

Hanson, N. 1989. Layperson's guide to agricultural drainage. Water Education Foundation, Sacramento, California, pp. 6-8.

Hem, J. D. 1970. Study and interpretation of the chemical characteristics of natural water, second edition. US Geological Survey Water-Supply Paper 1473:363 pp.

Hem, J. D. 1985. Study and interpretation of the chemical characteristics of natural water, third edition. US Geological Survey Water-Supply Paper 2254:263 pp.

Hill, M. N. 1963. The sea, Vol. 2. Interscience Publishers, New York, 554 pp.

Holland, H. 1979. Metals in black shales-a reassessment. Economic Geology 74:1676-1680.

Keith, M. L., and E. T. Degens. 1959. Geochemical indicators of marine and fresh-water sediments. Pages 38-61 in P. H. Abelson (ed.), Researches in geochemistry. Wiley \& Sons, New York.

Krauskopf, K. B. 1955. Sedimentary deposits of rare metals. Pages 411-462 in A. M. Bateman (ed.), Fiftieth Anniversary Volume 1905-1955, Economic Geology. Economic Publishing Company, Lancaster, Pennsylvania.

Krauskopf, K. B. 1967. Introduction to geochemistry. McGraw-Hill, San Francisco, California, 721 pp. 
Lakin, H. W. 1961. Vertical and lateral distribution of selenium in sedimentary rocks of Western United States. Pages 12-24 in M. S. Anderson, H. W. Lakin, K. C. Beeson, F. F. Smith, and E. Thacker (eds.), Selenium in agriculture. US Department of Agriculture Handbook 200.

Lakin, H. W. 1973. Selenium in our environment. Pages 96-111 in Trace Elements in the Environment. E. L. Kothny (ed.), Advances in chemistry series 123. American Chemical Society, Washington, DC.

Lakin, H. W., and H. G. Byers, 1941. Selenium occurrence in certain soils in the U.S. with a discussion of related topics; sixth report. US Department of Agriculture Technical Bulletin 783:27 pp.

Lakin, H. W., and D. F. Davidson, 1967. The relation of the geochemistry of selenium to its occurrence in soils. Pages 27-56 in O. H. Muth (ed.), Symposium: Selenium in biomedicine. AVI, Westport Connecticut.

Lemly, D. A., and G. J. Smith. 1987. Aquatic cycling of selenium: Implications for fish and wildlife. US Fish and Wildlife Leaflet 12, $12 \mathrm{pp}$.

Lettis, W. R. 1982, Late Cenozoic stratigraphy and structure of the western margin of the central San Joaquin Valley, California. US Geological Survey Open-File Report 82526, 203 pp.

McGuire, D. J. 1988. Stratigraphy, depositional history and hydrocarbon source-rock potential of the Upper Cretaceous--lower Tertiary Moreno Formation, central San Joaquin basin. California. PhD thesis. Stanford University, Stanford, California, $240 \mathrm{pp}$.

Milam, R. W. 1985. Biostratigraphy and sedimentation of the Eocene and Oligocene Kreyenhagen Formation, central California. PhD thesis. Stanford University, Stanford, California, $240 \mathrm{pp}$

Miller, M. R., R. N. Bergantino, W. M. Bermel, F. A. Schmidt, and M. K. Botz. 1980. Regional assessment of the saline-seep problem and a water-quality inventory of the Montana plains. Montana Bureau of Mines and Geology Open-File Report 42, $379 \mathrm{pp}$.

Naftz, D. L., R. B. See, and P. Ramirez. 1993. Selenium source identification and biogeochemical processes controlling selenium in surface water and biota, Kendrick Reclamation project, Wyoming, USA. Applied Geochemistry (in press).

NAS (National Academy of Sciences). 1976. Selenium: Medical and biologic effects of environmental pollutants. NAS, Washington, DC, 203 pp.

Ohlendorf, H. M., and J. P. Skorupa. 1989. Selenium in relation to wildlife and agricultural drainage water. Pages 314-338 in S. C. Carapella, Jr. (ed.), Proceedings of the fourth international symposium on uses of selenium and tellurium, 8-10 May 1989: Banff, Alberta, Canada. Selenium-Tellurium Development Association, Inc., Darien, Connecticut.

Park, C. F., Jr., and R. A. MacDiarmid. 1964. Ore deposits, 1st ed. Freeman, San Francisco, 475 pp.

Park, C. F., Jr., and R. A. MacDiarmid. 1970. Ore deposits, 2nd ed. Freeman, San Francisco, 490 pp.

Payne, M. B. 1951. Type Moreno Formation and overlying Eocene strata on the west side of the San Joaquin Valley,
Fresno and Merced, California. California Division of Mines and Geology Special Report 9:3-29.

Piper, D. Z., and C. M. Isaacs. 1993. Minor element sources in the Monterey Formation, California: Seawater chemistry of deposition (in press).

Presser, T. S., and I. Barnes. 1984. Selenium concentrations in waters tributary to and in the vicinity of Kesterson National Wildlife Refuge, Fresno and Merced counties, California. US Geological Survey Water Resources Investigations Report 84-4122, 26 pp.

Presser T. S., and I. Barnes. 1985. Dissolved constituents including selenium in waters in the vicinity of Kesterson National Wildlife Refuge and the west Grassland, Fresno and Merced counties, California. US Geological Survey Water Resources Investigations Report 85-4220, 73 pp.

Presser, T. S., and H. M. Ohlendorf. 1987. Biogeochemical cycling of selenium in the San Joaquin Valley, California. Environmental Management 11:805-821.

Presser, T. S., W. C. Swain, R. R. Tidball, and R. C. Severson. 1990. Geologic sources, mobilization, and transport of selenium from the California Coast Ranges to the western San Joaquin Valley: A reconnaissance study. US Geological Survey Water-Resources Investigations Report 90. $4070,66 \mathrm{pp}$.

Quinn, N. W., W. C. Swain, and D. T. Hansen. 1990. Assessment of ground-water pumping as a management option in drainage problem areas of the western San Joaquin Valley. Technical Information Record, San Joaquin Valley Drainage Program, Sacramento, California, $28 \mathrm{pp}$.

Raiswell, R., and R. A. Berner, 1987. Organic carbon losses during burial and thermal maturation of normal marine shales. Geology 15:853-856.

Rickard, D. T. 1970. The origin of framboids. Lithos 3:269293.

Rocky Mountain Association of Geologists. 1972. Cretaceous system. Pages 190-228 in W. W. Mallory (ed.-inchief), Geologic atlas of the Rocky Mountain region, USA. Hirschfeld Press, Denver, Colorado.

Schoellhamer, J. E., and D. M. Kinney. 1953. Geology of a part of Tumey and Panoche Hills, Fresno county, California. US Geological Survey Oil and Gas Investigations Map OM 128, scale 1:24,000.

SJVDP (San Joaquin Valley Drainage Program). 1990. A management plan for agricultural subsurface drainage and related problems on the westside San Joaquin Valley. SJVDP, Sacramento, California, $183 \mathrm{pp}$.

Skorupa, J. P., and H. M. Ohlendorf. 1991. Contaminants in drainage water and avian risk thresholds. Pages 345-368 in A. Dinar and D. Zilberman (eds.), The economics and management of water and drainage in agriculture. Kluwer Academic Publishers, Ncw York.

Tidball, R. R., R. C. Severson, J. M. McNeal, and S. A. Wilson. 1989. Distribution of selenium, mercury, and other elements in soils of the San Joaquin Valley and parts of the San Luis Drain Service Area, California. Pages 71-82 in A. Howard (ed.), Selenium and agricultural drainage: Implications for San Francisco Bay and the California environment. Proceedings of the third selenium symposium, 15 March 1986: Berkeley, California. The Bay Institute of San Francisco, Tiburon, California. 
Trelease, S. F., and O. A. Beath. 1949. Selenium: Its geological occurrence and its biological effects in relation to botany, chemistry, agriculture, nutrition, and medicine. Trelease and Beath, New York, $292 \mathrm{pp}$.

Trudinger, P. A., I. B. Lambert, and G. W. Skyring. 1972 Biogenic sulfide ores: A feasibility study. Ecomomic Geology 67:1114-1127.

USBR (US Bureau of Reclamation). 1991a. Draft environmental impact statement, San Luis Drainage Program, Central Valley Project, California. USBR, Sacramento, California, $270 \mathrm{pp}$.

USBR (US Bureau of Reclamation). 1991b. Kesterson Reservoir: Biological monitoring report and 1992 biological monitoring plan, pp. 1-1-11-4.

USEPA (US Environmental Protection Agency). Amended in 1987. National pollutant discharge elimination system. Clean Water Act 402:155.

USEPA (US Environmental Protection Agency). 1980a. Hazardous waste management system. Federal Register 45(98):33063-33285.

USEPA (US Environmental Protection Agency). 1980b. Ambient water quality criteria for selenium. EPA 440/587-006. USEPA, Washington, DC, $121 \mathrm{pp}$.
USEPA (US Environmental Protection Agency). 1991. Federal Register, 56(20):3538-3539.

Velinsky, D. J., and G. A. Cutter. 1991. Geochemistry of selenium in a coastal salt marsh. Geochimica et Cosmochimica Acta 55:179-191.

Vine, J. D., and E. B. Tourtelot. 1970. Geochemistry of black shale-a summary report. Economic Geology 65:253272.

Wedepohl, K. H. (cd.). 1970. Handbook of geochemistry, vol. 1I/2, Chapter 34. Springer-Verlag, New York.

Wiese, R. G., Jr. 1957. An occurrence of mineralized organic material in Nova Scotia. Economic Geology 52:76-82.

Whittig, L. D., A. E. Deyo, and K. K. Tanji. 1982. Evaporite mineral species in Mancos Shale and salt efflorescence, upper Colorado River basin. Soil Science Society of America Journal 46:645-651.

Yang, G. S., S. Wang, R. Zhou, and S. Sun. 1983. Endemic selenium intoxication of humans in China. American Journal of Clinical Nutrition 37:872-881.

Zies, E. G. 1929. The Valley of Ten Thousand Smokes, I, The fumarolic incrustations and their bearing on ore deposition. Papers from the Geophysical Laboratory of the Carnegie Institution 693, $61 \mathrm{pp}$. 